Олександр Васильович Батанов, доктор юридичних наук, профессор, провідний науковий співробітник Інституту держави і права ім. В.М. Корецького НАН України*

ORCID: 0000-0002-0239-4539

\title{
КОНЦЕПТУАЛЬНІ ПРОБЛЕМИ ЗАБЕЗПЕЧЕННЯ КОНТРОЛЮ У СФЕРІ МІСЦЕВОГО САМОВРЯДУВАННЯ: ТЕОРІЯ ТА ПРАКТИКА
}

Формування системи місцевого самоврядування в цілому та конституювання окремих форм здійснення його цілей і функцій, у тому числі й муніципальних контрольних механізмів зокрема, виявилося одним із найбільш складних завдань становлення демократії в України. Попри те, що Конституція України і профільний Закон України «Про місцеве самоврядування в Україні» ${ }^{1}$, декларуючи статус територіальної громади як провідного, центрального суб'єкта, безумовно, було і залишається прогресивним кроком на шляху до формування правової державності та громадянського суспільства, будуючи систему місцевого самоврядування крізь призму «людського вимірювання» ${ }^{2}$, тобто від конкретної особи, людської спільноти. Визнання місцевого самоврядування через первинність прав територіальної громади створювало й створює оптимальні конституційні умови для розвитку самоорганізації населення та функціонування місцевого самоврядування, суб'єкти якого, як свідчить зарубіжна практика, мали б стати «локальними осередками і інструментами громадянського суспільства, створеними самими жителями-сусідами, партнерами влади, а не анемічним, заорганізованим і залежним придатком державної машини»³.

Попри значні кроки у процесі становлення місцевого самоврядування, його функціональний потенціал в цілому та, зокрема, в аспекті здійснення контрольної діяльності, залишалися декларацією. Динаміки, механізму функціонування територіальних громад та їх самоорганізованих структур, насамперед у контрольній сфері, а слід - оптимальних умов для формування дієздатного місцевого самоврядування, на жаль, створити не вдалося.

Саме контроль за будь-яких моделей та форм здійснення місцевого самоврядування, про що свідчить його генезис та сучасна світова муніципальна практика, $є$ важливою функцією місцевого самоврядування та неодмінним етапом муніципального процесу щодо вирішення питань місцевого значення, який має велике значення в розкритті потенціалу локальної демократії. «Самостійність і правильна організація контролю, ще на початку XX сторіччя писав класик муніципальної науки М. Загряцков, - можлива тільки в тому випадку, якщо завдяки ефективному розділу праці між центром і місцями самоврядні структури можуть повністю присвятити себе господарським, соціальним та адміністративним функціям. Правильний розподіл праці, в свою чергу, означає, що центральна влада контролює діяльність муніципалітетів тільки з точки зору ії відповідності законам, надаючи нагляд над їх діями із точки зору доцільності самому населенню»4.

Безумовно, основні функції місцевого самоврядування та його суб'єктів, у тому числі й у сфері контролю, в цілому явища відносно стабільні, однак вони не $є$ незмінними. Незважаючи на багаторічний інертний рух муніципальної реформи (принаймні до 2014 р.), вони безперервно розвиваються та вдосконалюються в ході здійснення. Загальною тенденцією їх розвитку в сучасних умовах повинно стати підвищення ролі людського фактору у процесі вирішення питань місцевого значення. Світовий досвід свідчить: справжнє самоврядування можливе лише на основі безпосередньої творчої ініціативи самих місцевих жителів.

Самоврядування та самоорганізація не можуть і не повинні бути заформалізованими. Роль держави повинна мати прояв не в штучному інспіруванні місцевого самоврядування, а у партнерській його підтримці

(C) О.В. Батанов, 2019

* Oleksandr Batanov, Dr. hab. in Law, Professor, Leading Researcher of V.M. Koretsky Institute of State and Law of the NAS of Ukraine 
у вирішенні суспільно значущих справ. Система місцевого самоврядування має стати породженням суспільно-політичної творчості населення, з одного боку, та цілеспрямованих зусиль і підтримки держави, з другого. Тому розширювати права і контрольні функції місцевого самоврядування та його суб'єктів слід насамперед там, де найбільший ефект приносить місцева ініціатива.

Враховуючи, що місцеве самоврядування та самоорганізація населення - це багатовекторне (організаційно-політичне, економічне, соціально-культурне, управлінське тощо) явище, процес розвитку і вдосконалення муніципальних функцій та повноважень, особливо у контрольній сфері, складний і багатогранний. Безумовно, кожному напряму і виду муніципальної діяльності притаманні свої особливості, однак, в силу внутрішньої єдності системи функцій цих органів, вони (функції) мають багато спільного, що певною мірою і знаходить свій прояв у муніципальній діяльності локально організованих структур. Саме тому розвиток контрольних функцій та повноважень, удосконалення механізму їх реалізації зумовлюються внутрішніми i зовнішніми, об'єктивними і суб'єктивними факторами. Вагоме значення належить внутрішнім об'єктивним факторам (соціальним, економічним, духовно-культурним тощо). Однак найбільш важливе значення в розвитку контрольних функцій та повноважень має подальше зміцнення основ (механізмів) їх діяльності, зокрема правових, організаційних, фінансових, матеріально-технічних, наукових.

Спираючись на фундаментальні принципи організації і діяльності місцевого самоврядування, які закладені у Конституції України, профільному законодавстві та міжнародних стандартах місцевої демократії, від оптимальної реалізації якого залежить його ефективне функціонування, можна спроектувати і основні «магістральні» шляхи реформування й організаційно-структурних механізмів, матеріально-технічної та бюджетно-фінансової бази місцевого самоврядування, а також нормативно-правове закріплення цих перетворень.

Враховуючи, що фактично основним повсякденним реалізатором усіх функцій територіальних громад в умовах самоорганізації населення є обрані місцевими жителями органи та посадові особи місцевого самоврядування, вдосконалення потребує саме його організаційний механізм. Але якщо законодавцю певною мірою вдалося сконструювати загальну правову модель базових органів місцевого самоврядування - місцевих рад, їх виконавчих органів та посадових осіб, а також їх функцій та повноважень, то правовий статус та форми їх функціонування у сфері контролю багато у чому залишаються невизначеними. Втім, попри важливість таких об'єктивних чинників, як недосконалість законодавства, низький рівень кваліфікації посадових осіб місцевого самоврядування та його кадровий потенціал, передусім з точки зору організації та функціонування місцевого самоврядування варто звертати увагу на суб'єктивні моменти. Адже у своєму класичному розумінні місцеве самоврядування було й залишається є формою діяльності, яка здійснюється під власну відповідальність.

За словами В.П. Рубцова, сьогодні необхідним є подолання ментальної прірви у свідомості громадян між справами, що вирішуються кожним окремим пересічним жителем («свої» справи), і справами, які вирішуються на загальнодержавному рівні і сприймаються ним як політичні й абстрактні, до яких пересічному жителю майже нема діла, бо все одно він на них майже не впливає («чужі» справи). Тобто, вказує він, йдеться про формування поля «наших» справ, створення організаційно-правових і економічних засад для залучення жителів до повсякденної участі у суспільних справах за місцем проживання («наші» справи) поза межами власної квартири чи подвір'я (під’їд у місті, прилегла частина вулиці у селі), чи будинок, чи вулиця, чи квартал або куток села, селища міста, мікрорайон тощо 5 .

Так, наприклад, збільшення кількості інституцій, які спеціалізуються на наданні соціальних послуг населенню, активізація їх діяльності, розвиток децентралізації та самоорганізації також вимагає кардинальних змін у поглядах на муніципально-правову природу (у тому числі й контрольну) органів самоорганізації населення. Їх завдання, як локального інституційного ядра територіальної мікрогромади, насамперед повинні зводитися до акумуляції та генерації місцевих інтересів, виявлення важливих потреб населення, встановлення пріоритетів, пошуку оптимальних шляхів забезпечення питань місцевого значення, здійсненні громадського контролю за якістю соціальних послуг. Попри те, що органи самоорганізації населення за чинним законодавством не визначені як суб'єкти, що надають соціальні послуги та органи, що здійснюють контроль за їх якістю, вони мають всі можливості для здійснення такого контролю у своїх будинках. Вони можуть на місцях виявляти громадян, які потребують допомоги, повідомляти про них у відповідні органи, сприяти їм в отриманні соціальних послуг, моніторити роботу місцевих соціальних служб та їхніх працівників тощо. Адже, якщо виходити із поняття органу самоорганізації населення, принципів його діяльності та власних повноважень, стає зрозуміло, що органи самоорганізації населення органи самоорганізації населення $є$ тим суб'єктом, що може ефективно надавати соціальні послуги. Крім того, якщо передбачено можливість надавати соціальні послуги для громадських, благодійних та релігійних організацій, то вони зовсім не поступаються їм. Вони знайомі з проблемами окремих категорій громадян на місцях, можуть проконтролювати якість наданих соціальних послуг в будинках, тобто є близькими до людей 6 .

Вирішення нагальних проблем існування і функціонування органів самоорганізації населення щільно пов'язане 3 побудовою цілого комплексу взаємовідносин місцевого самоврядування 3 іншими суб'єктами суспільства й державою, які б встановлювали необхідний баланс їх інтересів та потреб7. Не викликає сумніву, що більш раціональні стосунки органів самоорганізації населення з іншими суб'єктами місцевого самоврядування та органами державної влади дадуть змогу ефективніше розподілити обсяг повноважень, які можуть бути делеговані державою територіальним громадам. 
Практика муніципального правокористування в сучасній Україні об'єктивно доводить, що удосконалення контрольних процедур і механізмів захисту прав місцевого самоврядування - важливе завдання муніципальної реформи. У цьому аспекті, наприклад, значний інтерес викликає запровадження інституту соціальних громадських інспекторів. Вважаємо абсолютно правильною пропозицію створення такої громадської інституції, метою якої стало б залучення органів самоорганізації населення та громадських об'єднань до активної роботи з надання соціальної допомоги та запровадження відповідного громадського контролю. Для цього доцільно передбачити внесення необхідних змін до законодавства України про соціальні послуги та про органи самоорганізації населення, що, у перспективі, сприятиме як посиленню соціальної, так і контрольної функції самоорганізації населення, підвищенню ефективності проведенню виконавчими органами місцевих рад соціальної політики на місцях ${ }^{8}$.

Зарубіжний досвід свідчить про гнучкість інституту соціальних громадських інспекторів, його здатність пристосовуватися до місцевих умов. Запровадження інституту соціальних громадських інспекторів стало б важливим кроком у розвитку демократичних процесів, спрямованих на зміцнення системи контролю у сфері місцевого самоврядування, децентралізацію соціальної політики, захист особи - члена територіальної мікрогромади, посилення гарантій реалізації муніципальних прав і свобод людини, сприятиме покращенню управління територіями та гуманізації відносин «особа - органи самоорганізації населення - представницький орган місцевого самоврядування (місцева рада) - держава», що, безумовно, матиме позитивний вплив на ефективне здійснення завдань та функцій місцевого самоврядування.

Також процес муніципального розвитку об'єктивно вимагає вдосконалення інститутів прямого волевиявлення в місцевому самоврядуванні, особливо на мікролокальному рівні, тобто безпосередньо за місцем проживання населення. Закон України «Про місцеве самоврядування в Україні» фактично обмежується лише встановленням таких форм, відносячи до них загальні збори громадян (ст. 8), місцеві ініціативи (ст. 9) та громадські слухання (ст. 13). Кожна з означених форм безпосередньої муніципальної демократії потребує окремої детальної регламентації та відіграє вагому роль у процесі самоорганізації населення. Така ситуація суттєво ускладнює впровадження цих форм у практику територіальних громад і не сприяє подальшому розвитку самоорганізації населення, залученню жителів до участі у вирішенні питань місцевого значення. Особливо відчутними ці прогалини у законодавстві є в аспекті реалізації потенціалу місцевого самоврядування та самоорганізації населення у контрольній сфері.

Також слід звернути увагу на проблеми розвитку муніципального законодавства в незалежній Україні. Це має прояв у тому, що нормативні акти, які діють на загальнодержавному рівні, подекуди не лише не усувають наявні прогалини щодо організації та функціонування місцевого самоврядування, а ще більш заплутують ситуацію. Тому, попри вагомий потенціал законодавчого регулювання профільних суспільних відносин у сфері муніципальної безпосередньої демократії та самоорганізації населення, акцентуємо на значенні та особливій ролі статутної регламентації видів прямої муніципальної демократії як найбільш оптимальної та гнучкої форми нормотворчості. У цьому контексті варто погодитись з В.П. Рубцовим, на думку якого, статут - це один із найважливіших інструментів залучення громади і головне в ньому - не тільки норми, а насамперед «процес активізації громади» 9.

На потенціал статутної регламентації форм муніципальної демократії, у тому числі й під кутом зору муніципальної контрольної діяльності, вже тривалий час звертають увагу експерти 3 проблем місцевого самоврядування ${ }^{10}$, якими, на наш погляд, абсолютно справедливо ставиться питання про необхідність передачі регулювання діяльності органів самоорганізації населення на локальний рівень - рівень територіальної громади, а також доводиться перевага локального регулювання статусу громадських слухань, місцевих ініціатив, передусім шляхом прийняття статутів територіальних громад, а також прийняття окремих положень, які регламентують відповідні питання у конкретному населеному пункті.

Отже, важливою і необхідною умовою становлення й розвитку контрольних функцій місцевого самоврядування та його колосального потенціалу у сфері контролю є вдосконалення правової бази місцевого самоврядування. Яскравою ілюстрацією тому є практика вісімнадцяти років застосування чинного Закону України «Про органи самоорганізації населення» 11 , що показала його суттєві недоліки. А саме: закон не врегульовує, а зарегульовує організаційні аспекти функціонування самоврядних спільнот, діяльність яких зосереджена на спільному вирішенні проблем покращення співжиття громадян на певній невеликій частині території населеного пункту. Чинником, що активізує утворення цих спільнот, є факт проживання по сусідству. Закон фактично звужує цілі і завдання діяльності таких самодіяльних спільнот, жорстко прив'язуючи їх діяльність до діяльності місцевої влади (функціонально, економічно, у часі), трактує органи самоорганізації населення як допоміжну ланку місцевої влади, її продовження до будинку, вулиці, мікрорайону, а не як організаційну форму активності населення, не створює реальних правових гарантій діяльності органів самоорганізації населення, не визначає реальних фінансово-економічних джерел і їх статусу як економічних суб’ єктів, зосереджуючись в основному на організаційно-правових аспектах.

Прийнятий на основі Конституції України та існуючий нині Закон України «Про органи самоорганізації населення» концептуально відтворює характерне з радянського періоду підозріле ставлення владних кіл до самодіяльності населення на території проживання, тобто, поза межами «трудового колективу». За часів соціалізму будь-яка громадська активність за місцем роботи могла бути проконтрольованою адміністративною ієрархією, партійною і профспілковою організацією та іншими квазігромадськими організаціями, що мали абсолютну більшість формальних осередків саме на підприємствах, а не на територіях. 
У «трудовому колективі» головними інструментами впливу на людей були заробітна платня і посадове просування. Інша справа - територія проживання. Там цих важелів впливу і контролю майже не було. Тому 3 боку влади до самодіяльності у цій менш контрольованій сфері завжди ставились 3 великою підозрою. Активність за місцем проживання владою не підтримувалась, не стимулювалась, а іноді й просто гасилась. Людей привчали до соціальної пасивності і споживацтва: «Держава все зробить і дасть. Вам треба тільки виконувати вказівки на роботі, ніякої ініціативи не потрібно. За вас думає партія і уряд, а ви працюйте...» У результаті багатолітнього тренінгу пасивності у радянський період $\mathrm{i}$, як наслідок, розквіту індивідуалізму під час економічної кризи періоду незалежності українське суспільство досі залишається вкрай атомізованим і роз'єднаним.

Найбільш актуальними проблемами організації та функціонування місцевого самоврядування були й залишаються питання реалізації та захисту прав людини. Важливість і актуальність даної теми не треба доводити, оскільки права людини є органічним компонентом демократичного політичного простору, інструментом гуманізації суспільних відносин, формування творчої особистості та становлення постіндустріального людства. На права людини покладають розв'язання ряду не лише внутрішніх, міжнародних та глобальних завдань, а проблем локально-регіонального значення, пов'язаних із функціонуванням територіальних громад та їх органів. Права знаходять свою присутність практично в кожній сфері життєдіяльності людини, відображаючи іiі життя в особливому якісному стані, пов'язаному із затвердженням у громадській свідомості та практиці ідеї свободи особистості.

Слід зазначити, що гарантованість прав людини у сфері місцевого самоврядування - це своєрідний зовнішній механізм обмеження свавілля місцевих чиновників, а також централістських «випадів» державної влади, яка завжди прагне до розширення та посилення своєї присутності у всіх сферах життя. Тому необхідно постійно створювати нові та вдосконалювати існуючи механізми організаційного та правового характеру проти зловживання владою. Вдосконалення таких контрольно-наглядових процедур і механізмів захисту прав місцевого самоврядування - важливе завдання демократичної держави.

У зв'язку з цим особливий інтерес являє собою конституційно-правовий інститут народного захисника, або омбудсмана, який успішно функціонує в багатьох країнах світу. Як свідчить зарубіжний досвід, обсяг контрольної функції омбудсмана залежить від кола органів та посадових осіб, на яких розповсюджується юрисдикція омбудсмана, а також від обсягу прав і свобод людини і громадянина, дотримання котрих вони контролюють. При цьому загальнодержавний омбудсман як одна особа не завжди здатен охопити своєю діяльністю всі сфери та рівні державного та місцевого життя, в яких порушуються (можуть порушуватися) права окремої особи. Тому у деяких країнах світу передбачено посади представників загальнонаціональних омбудсманів на місцях, у зв'язку з чим особливий інтерес викликає інститут регіонального та місцевого уповноваженого з прав територіальних громад. Тобто, світова практика йде шляхом локалізації та муніципалізації інституту омбудсмана. Це робиться для того, щоб даний інститут мав можливість в повну силу, миттєво реалізувати свої контрольно-наглядові функції у випадку порушення прав людини, у тому числі й передусім у рамках територіальних громад як первинних суб'єктів місцевого самоврядування.

На наш погляд, запровадження інституту муніципальних омбудсманів допомогло б ліквідувати існуючі прогалини у сфері муніципального контролю та функціонування механізмів захисту прав людини, стало б важливим кроком у розвитку демократичних процесів, спрямованих на зміцнення системи місцевого самоврядування, захист особи - члена територіальної громади, посилення гарантій реалізації муніципальних прав людини, сприяло б покращенню управління територіями та гуманізації відносин «особа - орган місцевого самоврядування - держава», що, з одного боку, безумовно мало б позитивний вплив на ефективне здійснення функцій місцевого самоврядування, a, по-друге, не лише доповнило б існуючу систему гарантій прав громадян, а й стало б новим органом, який забезпечує жителям - членам територіальних громад ще один правозахисний канал у випадках порушення або обмеження їх прав.

Безумовно, ці приклади контрольної діяльності суб'єктів місцевого самоврядування (як 3 точки зору сучасного стану, так і перспективного розвитку) не є вичерпними. Свого удосконалення у контексті муніципальної реформи потребують і інші інститути муніципальної демократії. Так, у контексті удосконалення контрольного механізму у системі місцевого самоврядування колосальний інтерес та перспективи має інститут мирових суддів. Про потенціал мирової юстиції й актуальність цього питання в аспекті здійснення муніципальної реформи свідчать відповідні законопроектні роботи ${ }^{12}$, доктринальні розробки вітчизняних вченихконституціоналістів ${ }^{13}$ та колосальний зарубіжний досвід ${ }^{14}$. Адже сучасний стан розвитку держави та суспільства, низка змін у законодавстві з питань правового захисту законних прав та інтересів суб'єктів правовідносин зумовлює об'єктивну необхідність удосконалення законодавства, яке регулює процес вирішення спірних відносин на рівні територіальних громад мировими суддями. Як свідчить світовий досвід, мирове судочинство як спосіб вирішення приватних суперечок має стати важливою складовою сучасної правової моделі захисту й реалізації прав та інтересів учасників суспільних відносин.

Необхідність впровадження інституту мирових суддів зумовлена, зокрема, з погляду на такий критерій, як доступ до правосуддя. Введення інституту мирових суддів - це реальний шанс зменшити навантаження на місцеві загальні суди, оскільки відносно нескладні (малозначимі) справи та вимоги за невеликою ціною позову можуть бути передані на розгляд мирового судді. Інституціоналізація мирових суддів може стати формою субсидіарного чи альтернативного способу врегулювання спорів поруч з такими засобами вирішення конфліктів, як третейське судочинство та посередництво (медіація). 
Відсутність інституту мирових суддів у судовій системі України - свідчення того, що чинна судова система повністю відірвана від територіальних громад. Тому питання про впровадження цього інституту в систему місцевого самоврядування (після змін до Конституції України - в судову систему) є актуальним і потребує законодавчого вирішення.

Подолання цих та інших проблем муніципальної теорії та практики допоможе вирішити найбільш принципове питання - проблему комунізації, тобто формування дієздатної територіальної громади. Без цього місцеве самоврядування залишиться лише у вигляді привабливої демократичної декларації. Формування альтернативних та ефективних контрольних механізмів у територіальних громадах вказує, що самоврядний процес $\epsilon$ формою функціонування територіальної громади, за якою чинне законодавство визнає виключне право на місцеве самоврядування. Таке розуміння самоврядного процесу визначає його як вид демократичного, а отже, й політичного процесу, оскільки за своєю суттю є прикладом самостійного здійснення влади місцевою спільнотою. Демократія будується знизу, а місцева політична спільнота визнається мікромоделлю всього суспільства, тому самоврядний процес як політичний процес на місцевому рівні визнано основою демократичного процесу, від якості функціонування якого залежить успіх демократії на загальнодержавному рівні15. Саме тому система самоорганізації населення - оптимальна школа суспільно-політичного зростання та ідеальне середовище, в якому могли б викристалізовуватися механізми публічно-правової відповідальності та контролю будь-яких владних структур.

Тільки реалізація протягом тривалого часу в свідомості жителів - членів територіальних громад стійких антіетатистських установлень, корінні зміни стереотипів суспільно-політичної поведінки широких верств населення, його самоорганізація та самодисципліна, формування патріотичних настроїв можуть у майбутньому стати основою для нівелювання конфлікту державних та громадських інтересів, формування оптимального балансу між публічним і приватним началом.

Лише у випадку такого поєднання індивідуальних сил з силами суспільними, як це відбувається в рамках місцевого самоврядування та, особливо, самоорганізації населення, можна добитися того, чого державна влада, хоч якою б вона потужною та ефективною була, не в змозі зробити. Якщо до цього додати, що саме 3 місцевим самоврядуванням жителі сіл та міст кожен день мають безпосереднє і найбільш щільне спілкування, формуючи, контролюючи їх діяльність та беручи участь у їх роботі, стає цілком зрозумілим, чому децентралізація влади та самоорганізація населення має стати одним із основоположних векторів конституційноправової модернізації в сучасній Україні.

1 Про місцеве самоврядування в Україні: Закон України від 21 травня 1997 р. Відомості Верховної Ради України. 1997. № 24. Ст. 170 .

2 Документ Копенгагенского совещания Конференции по человеческому измерению СБСЕ : Копенгаген, 29 июня 1990 г. Офіиійний сайт Верховної Ради Украӥни. URL: http://zakon1.rada.gov.ua/cgi-bin/laws/main.cgi?page=1\&nreg=994_0824; Парижская хартия для новой Европы : Итоговый документ Совещания по безопасности и сотрудничеству в Европе, состоявшегося в Париже 21 ноября 1990 г. Офіиійний сайт Верховної Ради Украӥни. URL: http://zakon1.rada.gov.ua/cgi-bin/laws/main.cgi?nreg=995_058

3 Рубцов В.П. Про суперечності становлення інституту органів самоорганізації населення та нову концепцію їх створення. ГО «Інститут місиевої демократії». URL: https://sites.google.com/site/ngoildua/nasi-publikacii

4 Загряцковь М. Соціальная деятельность городского самоуправленія на Западе. Вип. I: Проблемы муниципализаціи. Кіевъ, 1906. С. 67-68.

5 Рубцов В.П. Вказана праця.

6 Дембіцька Т. Соціальна функція ОСНів: надання соціальних послуг чи контроль за їх наданням? Посилення соціальної функиії органів самоорганізаиії населення: восьма всеукраїнська науково-практична конференція 3 питань самоорганізації населення: зб. матеріалів. (Горлівка, 15-16 листопада 2013 р.) / під ред. А.С. Крупника, В.В. Кіщенко. Одеса: ПП «Євродрук», 2013. C. $74-76$.

${ }^{7}$ Вишневський С.Ф. Функції органів самоорганізації населення як суб'єктів місцевого самоврядування: проблеми теорії та практики: дис. ... канд. юрид. наук: 12.00.02. Маріуполь, 2014. С. 171-187.

8 Чунаев О. Соціальна функція органів самоорганізації столиці: деякий досвід та нормативна база. Посилення соиіальної функиії органів самоорганізаиіï населення: восьма всеукраїнська науково-практична конференція 3 питань самоорганізації населення: зб. матеріалів (Горлівка, 15-16 листопада 2013 р.) / під ред. А. С. Крупника, В. В. Кіщенко. Одеса: ПП «Євродрук», 2013. C. $84-87$.

${ }^{9}$ Самостійність місцевих влад та розподіл повноважень між ними : організація місцевого самоврядування відповідно до принципів Європейської хартії місцевого самоврядування : Матеріали міжнар. конф. (м. Київ, 11-12 червня 2002 р.) / Рада Європи ; Фонд сприяння місцевому самоврядуванню України / В. Кравченко (упоряд.), М. Пухтинський (упоряд.). Київ : Логос, 2002. С. 111

10 Зайцева І.О. Конституційно-правове забезпечення статутної нормотворчості у місцевому самоврядуванні в Україні: дис. ... канд. юрид. наук: 12.00.02. Маріуполь, 2013. 236 с.; Заяць Д.Д. Статутне регулювання системи місцевого самоврядування в Україні: дис. ... канд. наук з держ. упр. : спец.: 25.00.04. Львів, 2010. 211 с.; Ідесіс І.В. Статути територіальних громад українських міст: проблеми теорії та практики : дис. ... канд. юрид. наук : 12.00.02. Ужгород, 2016. 222 с.; Орловський О.С. Проблеми локальної нормативно-правової регламентації місцевих ініціатив (на прикладі м. Одеси). Сайт Національної бібліотеки Украӥни ім. В.I. Вернадського. URL: http://www.nbuv.gov.ua/portal/Soc_Gum/VKhnuvs/2009_46/46/22.pdf; Орловський O. Регулювання форм локальної демократії статутами територіальних громад. Юридический вестник. 2009. № 2. С. 24-30; Орловський О. Нормативно-правова регламентація загальних зборів членів територіальної громади на локальному рівні (На матеріалах міста Суми). Юридический вестник. 2010. № 1. С. 13-17; Чудик Н.О. Статут територіальної громади як джерело конституційного права України : дис. ... канд. юрид. наук : 12.00.02. Київ, 2011. 228 с. та ін. 
11 Про органи самоорганізації населення: Закон України від 11 липня 2001 р. Відомості Верховної Ради України. 2001. № 48. Ст. 254.

12 Проект Закону України «Про мирових суддів територіальних громад», внесений народними депутатами України А.С. Матвієнком та О.М. Бондарем. Реєстр. № 3291 від 10.10.2008. Сайт Верховної Ради Украӥни. URL: http://w1.c1.rada.gov. ua/pls/zweb2/webproc4_2?pf3516=3291\&skl=7

13 Кампо В.М. Мирові судді та громадські мирові судді в Україні: проблеми та перспективи впровадження. Київ: Ін-т громадян. сусп-ва: ТОВ «ІКЦ Леста», 2007. 40 с. (Покращення доступу сільського населення до правосуддя. Проект. Кн. 2).

14 Бурий А., Таратула Р., Тополевський Р., Тополевська Л. Міжнародний досвід діяльності інститутів мирового судді, суду присяжних, народних засідателів та пропозиції щодо можливостей його застосування в Україні. Львів: Регіональний громадський фонд «Право і Демократія», 2009. 131 с.

15 Осипов А.В. Місце та роль самоврядних процесів у демократизації сучасного українського суспільства : автореф. дис. ... канд. політ. наук : 23.00. Одеса, 2008. С. 9-10, 11.

\section{References:}

Zakon Ukrainy «Pro mistseve samovriaduvannia v Ukraini» vid 21 travnia 1997 r. Vidomosti Verkhovnoi Rady Ukrainy. 1997. № 24. St. 170 [in Ukrainian].

Dokument Kopenhahenskoho soveshchanyia Konferentsyy po chelovecheskomu yzmerenyiu SBSE: Kopenhahen, 29 yiunia 1990 h. Ofitsiinyi sait Verkhovnoi Rady Ukrainy. URL: http://zakon1.rada.gov.ua/cgi-bin/laws/main.cgi?page=1\&nreg=994_0824 (data zvernennia: 01.09.2019) [in Russian].

Parizhskaja hartija dlja novoj Evropy: Itogovyj dokument Soveshhanija po bezopasnosti i sotrudnichestvu v Evrope, sostojavshegosja v Parizhe 21 nojabrja 1990 g. Ofitsiinyi sait Verkhovnoi Rady Ukrainy. URL: http://zakon1.rada.gov.ua/cgi-bin/laws/main.cgi? nreg=995 058 (data zvernennia: 01.09.2019) [in Russian].

Rubtsov, V.P. Pro superechnosti stanovlennia instytutu orhaniv samoorhanizatsii naselennia ta novu kontseptsiiu yikh stvorennia. HO «Instytut mistsevoi demokratii». URL: https://sites.google.com/site/ngoildua/nasi-publikacii (data zvernennia: 01.09.2019) [in Ukrainian].

Zagrjackov, M. (1906) Social'naja dejatel'nost' gorodskogo samoupravlenija na Zapade. Vip. I: Problemy municipalizacii. (pp. 67-68). Kiev [in Russian].

Dembitska, T. (2013) Sotsialna funktsiia OSNiv: nadannia sotsialnykh posluh chy kontrol za yikh nadanniam? Vosma vseukrainska naukovo-praktychna konferentsiia z pytan samoorhanizatsii naselennia «Posylennia sotsialnoi funktsii orhaniv samoorhanizatsii naselennia. Zbirnyk materialiv». Horlivka, 15-16 lystopada 2013 roku (pp. 74-76). Odesa: PP «Ievrodruk» [in Ukrainian].

Vyshnevskyi, S.F. (2014) Funktsii orhaniv samoorhanizatsii naselennia yak subiektiv mistsevoho samovriaduvannia: problemy teorii ta praktyky: dys. na zdobuttia nauk. stupenia kand. yuryd. nauk: spets. 12.00 .02 «Konstytutsiine pravo; munitsypalne pravo». (pp. 171-187). Mariupol [in Ukrainian].

Chunaev, O. (2013) Sotsialna funktsiia orhaniv samoorhanizatsii stolytsi: deiakyi dosvid ta normatyvna baza. Vosma vseukrainska naukovo-praktychna konferentsiia z pytan samoorhanizatsii naselennia «Posylennia sotsialnoi funktsii orhaniv samoorhanizatsii naselennia. Zbirnyk materialiv». (pp. 84-87). Horlivka, 15-16 lystopada 2013 roku Odesa: PP «Ievrodruk» [in Ukrainian].

Zaitseva, I.O. (2013) Konstytutsiino-pravove zabezpechennia statutnoi normotvorchosti u mistsevomu samovriaduvanni v Ukraini: dys. na zdobuttia nauk. stupenia kand. yuryd. nauk: spets. 12.00.02 «Konstytutsiine pravo; munitsypalne pravo». Mariupol [in Ukrainian].

Zaiats, D.D. (2010). Statutne rehuliuvannia systemy mistsevoho samovpiaduvannia v Ukpaini: dyc. na zdobuttia nauk. ctup. kand. nauk z depzh. upp.: cpets.: 25.00.04 «Mictseve camovpiaduvannia». Lviv [in Ukrainian].

Idesis, I.V. (2016) Statuty terytorialnykh hromad ukrainskykh mist: problemy teorii ta praktyky : dys. na zdobuttia nauk. stupenia kand. yuryd. nauk: spets. 12.00 .02 «onstytutsiine pravo; munitsypalne pravo». Uzhhorod [in Ukrainian].

Kravchenko, V. (uporiad.), Pukhtynskyi, M. (uporiad.). (2002) Samostiinist mistsevykh vlad ta rozpodil povnovazhen mizh nymy. Orhanizatsiia mistsevoho samovriaduvannia vidpovidno do pryntsypiv Yevropeiskoi khartii mistsevoho samovriaduvannia. Materialy mizhnar. konf. m. Kyiv, 11-12 chervnia 2002 r. Kyiv: Lohos [in Ukrainian].

Orlovskyi, O.S. Problemy lokalnoi normatyvno-pravovoi rehlamentatsii mistsevykh initsiatyv (na prykladi m. Odesy). Sait Natsionalnoi biblioteky Ukrainy im. V.I. Vernadskoho. URL: http://www.nbuv.gov.ua/portal/Soc_Gum/VKhnuvs/2009_46/46/22.pdf (data zvernennia: 01.09.2019) [in Ukrainian].

Orlovskyi, O. (2009). Rehuliuvannia form lokalnoi demokratii statutamy terytorialnykh hromad. Yurydycheskyi vestnyk. № 2 [in Ukrainian].

Orlovskyi, O. (2010). Normatyvno-pravova rehlamentatsiia zahalnykh zboriv chleniv terytorialnoi hromady na lokalnomu rivni (Na materialakh mista Sumy). Yurydycheskyi vestnyk. № 1 [in Ukrainian].

Chudyk, N.O. (2011) Statut terytorialnoi hromady yak dzherelo konstytutsiinoho prava Ukrainy: dys. na zdobuttia nauk. stupenia kand. yuryd. nauk: spets. 12.00 .02 «Konstytutsiine pravo; munitsypalne pravo». Kyiv [in Ukrainian].

Zakon Ukrainy «Pro orhany samoorhanizatsii naselennia» vid 11 lypnia 2001 r. Vidomosti Verkhovnoi Rady Ukrainy. 2001 . № 48. St. 254 [in Ukrainian].

Proekt Zakonu Ukrainy «Pro myrovykh suddiv terytorialnykh hromad», vnesenyi narodnymy deputatamy Ukrainy Matviienkom, A.S. ta Bondarem, O.M. Reiestr. № 3291 vid 10.10.2008. Sait Verkhovnoi Rady Ukrainy. URL: http://w1.c1.rada.gov.ua/pls/zweb2/ webproc4_2?pf3516=3291\&skl=7(data zvernennia: 01.09.2019) [in Ukrainian].

Kampo, V.M. (2007). Myrovi suddi ta hromadski myrovi suddi v Ukraini: problemy ta perspektyvy vprovadzhennia. Kyiv: In-t hromadian. Susp-va: TOV «IKTs Lesta» [in Ukrainian].

Buryi, A., Taratula, R., Topolevskyi R., Topolevska, L. (2009) Mizhnarodnyi dosvid diialnosti instytutiv myrovoho suddi, sudu prysiazhnykh, narodnykh zasidateliv ta propozytsii shchodo mozhlyvostei yoho zastosuvannia v Ukraini. Lviv: Rehionalnyi hromadskyi fond «Pravo i Demokratiia» [in Ukrainian].

Osypov, A.V. (2008) Mistse ta rol samovriadnykh protsesiv u demokratyzatsii suchasnoho ukrainskoho suspilstva: avtoref. dys. ... kand. polit. nauk: 23.00 .02 «Politychni instytuty ta protsesy». (pp. 9-10, 11). Odesa [in Ukrainian]. 
Резюме

Батанов О.В. Концептуальні проблеми забезпечення контролю у сфері місцевого самоврядування: теорія та практика.

У статті досліджуються конституційно-правові проблеми організації та функціонування місцевого самоврядування в контексті контрольної діяльності у муніципальній сфері. Висвітлюється питання щодо системи та форм контрольної діяльності суб'єктів місцевого самоврядування у вітчизняній і зарубіжній юридичній практиці. Така постановка питання обумовлюється тим, що питання щодо місця й ролі контролю у системі місцевого самоврядування, його правової природи, співвідношення та взаємодії з іншими формами муніципальної діяльності належать до найбільш дискусійних у сучасній конституційній теорії.

Ключові слова: публічна влада; муніципальна влада; місцеве самоврядування; народовладдя; територіальна громада; питання місцевого значення; контроль.

\section{Резюме}

Батанов А.В. Концептуальные проблемы обеспечения контроля в сфере местного самоуправления: теория и практика.

В статье исследуются конституционно-правовые проблемы организации и функционирования местного самоуправления в контексте контрольной деятельности в муниципальной сфере. Освещается вопрос системы и форм контрольной деятельности субъектов местного самоуправления в отечественной и зарубежной юридической практике. Такая постановка вопроса объясняется тем, что вопросы о месте и роли контроля в системе местного самоуправления, его правовой природы, соотношения и взаимодействия с другими формами муниципальной деятельности относятся к наиболее дискуссионным в современной конституционной теории.

Ключевые слова: публичная власть; муниципальная власть; местное самоуправление; народовластие; территориальная община; вопросы местного значения; контроль.

\section{Summary}

Oleksandr Batanov. Conceptual problems of ensuring control in the field of local self-government: theory and practice.

The article examines the constitutional and legal problems of the organization and functioning of local self-government in the context of control activities in the municipal sphere. It is argued that control over any model and form of local self-government, as evidenced by its genesis and modern world municipal practice, is an important function of local self-government and an indispensable stage of the municipal process for solving local issues, which is of great importance in unlocking the potential of local democracy.

The question of the system and forms of control activities of subjects of local government in domestic and foreign legal practice is highlighted. This formulation of the question is explained by the fact that questions about the place and role of control in the system of local self-government, its legal nature, correlation and interaction with other forms of municipal activity are among the most controversial in modern constitutional theory.

The practice of municipal law enforcement in modern Ukraine objectively proves that improving the control procedures and mechanisms of protecting local self-government rights is an important task of municipal reform. In this aspect, the role and importance of self-organization bodies, as subjects of local self-government, which have significant control potential, is shown. The introduction of the Institute of Social Public Inspectors is also of great interest. The author states that the creation of a public institution aimed at involving the self-organization bodies of the population and public associations in the active work of providing social assistance and introducing appropriate public control.

Also, the process of municipal development objectively requires the improvement of the institutions of direct expression of will in local self-government, especially at the micro-local level, that is, directly at the place of residence of the population. Gaps in the legislation are particularly noticeable in terms of realizing the potential of direct municipal democracy and self-organization of the population in the control sphere.

The article focuses on the peculiarities and significance of the statutory regulation of forms of municipal democracy, including from the perspective of municipal control activities, for which experts on problems of local self-government have been paying attention for a long time.

The author draws attention to the need to introduce the Institute of Municipal Ombudsmen. This would eliminate the existing gaps in the sphere of municipal control and functioning of human rights protection mechanisms, would be an important step in the development of democratic processes aimed at strengthening the system of local self-government, protection of the individual - member of the territorial community, strengthening the guarantees for the implementation of municipal human rights, would promote management of territories and humanization of relations «person - body of local self-government - state». This would have a positive impact on the effective exercise of local self-government functions, would substantially complement the existing system of citizens' rights guarantees and would become a new body providing residents of territorial communities with another human rights channel in cases of violation or restriction of their rights.

The importance of strengthening other forms of control activities in local self-government is proved. In particular, in the context of improving the control mechanism in the system of local self-government, the institute of magistrates has tremendous interest and prospects.

Key words: public authority, municipal authority, local government, democracy, territorial community, local issues, the control. 